\title{
Livestock intensification potential in Brazil based on agricultural census and satellite data analysis
}

\author{
Arielle Elias Arantes ${ }^{(1)}$, Victor Rezende de Moreira Couto(2), Edson Eyji Sano( ${ }^{(3)}$ and Laerte Guimarães Ferreira(1) \\ (1)Universidade Federal de Goiás, Laboratório de Processamento de Imagens e Geoprocessamento, Campus II Samambaia, Caixa \\ Postal 131, CEP 74001-970 Goiânia, GO, Brazil. E-mail: aearantes@gmail.com, laerte@ufg.br (2)Universidade Federal de Goiás, \\ Escola de Veterinária e Zootecnia, Campus Samambaia, Avenida Esperança, s/no, Campus Universitário, CEP 74690-900 Goiânia, \\ GO, Brazil. E-mail: victorzootecnista@ufg.br ${ }^{(3)}$ Embrapa Cerrados, BR-020, Km 18, CEP 73301-970 Planaltina, DF, Brazil. E-mail: \\ edson.sano@embrapa.br
}

\begin{abstract}
The objective of this work was to evaluate the potential of livestock intensification in Brazil. Beef cattle stocking rates were estimated according to agricultural census data on livestock production in Brazilian municipalities. Pasture carrying capacity was obtained by combining moderate resolution imaging spectroradiometer (Modis) images of gross primary productivity and data on dry matter demand per animal unit (AU). Cattle stocking rate for Brazil, in 2014/2015, was $0.97 \mathrm{AU} \mathrm{ha}^{-1}$, and the carrying capacity was 3.60 $\mathrm{AU} \mathrm{ha}{ }^{-1}$; therefore, there is an average livestock intensification potential of $2.63 \mathrm{AU} \mathrm{ha}^{-1}$. The highest average intensification potential was observed for the Southern region (3.62 $\left.\mathrm{AU} \mathrm{ha}^{-1}\right)$, and the lowest for the Northern (2.13 AU ha-1) and Northeastern regions $\left(2.22 \mathrm{AU} \mathrm{ha}^{-1}\right)$. It is possible to estimate cattle stocking rate, pasture carrying capacity, and potential of livestock intensification by integrating data on agricultural census and remote sensing.
\end{abstract}

Index terms: Brazilian pasturelands, cattle stocking rate, gross primary productivity, livestock intensification, Modis GPP, pasture carrying capacity.

\section{Potencial de intensificação da pecuária no Brasil baseado na análise de dados censitários e de satélite}

\begin{abstract}
Resumo - O objetivo deste trabalho foi avaliar o potencial de intensificação da pecuária no Brasil. A taxa de lotação de bovinos de corte foi estimada de acordo com dados censitários agrícolas da produção pecuária municipal. A capacidade de suporte das pastagens foi obtida pela combinação de imagens "moderate resolution imaging spectroradiometer" (Modis) de produtividade primária bruta e de dados da demanda diária de matéria seca por unidade animal (UA). A lotação bovina no Brasil, em 2014/2015, foi de 0,97 UA ha , e a capacidade de suporte de 3,60 UA ha ${ }^{-1}$; portanto, há potencial de intensificação médio de 2,63 UA ha ${ }^{-1}$. O maior potencial de intensificação médio foi observado na região Sul $\left(3,62 \mathrm{UA} \mathrm{ha}^{-1}\right)$, e os menores nas regiões Norte $\left(2,13 \mathrm{UA} \mathrm{ha}^{-1}\right)$ e Nordeste $\left(2,22 \mathrm{UA} \mathrm{ha}^{-1}\right)$. É possível estimar a taxa de lotação bovina, a capacidade de suporte das pastagens e o potencial de intensificação da pecuária ao integrar dados do senso agrícola e de sensoriamento remoto.
\end{abstract}

Termos para indexação: pastagens brasileiras, taxa de lotação bovina, produtividade primária bruta, intensificação da pecuária, Modis GPP, capacidade de suporte da pastagem.

\section{Introduction}

Worldwide, livestock occupies $30 \%$ of the arable land, accounts for $40 \%$ of the agricultural gross domestic product, and provides income to more than 1.3 billion people (Herrero et al., 2013). Of the land used for grazing, about 20\% (680 million hectares) is estimated to be degraded due to inappropriate pasture management and meat production beyond its carrying capacity (Postel, 1998). Knowledge on pasture carrying capacity allows identifying areas that are environmentally vulnerable or even where grazing can be intensified (Ebrahimi et al., 2010).

In Brazil, cattle raising is an extensive activity, which adopts low levels of technology and is mostly pasture dependent (Paulino et al., 2011). In this scenario, livestock intensification can make available more areas for food production and for environmental conservation (Bowman et al., 2012; Strassburg et al., 2014). Since this intensification depends on pasture quality, it results in shorter raising periods until

Pesq. agropec. bras., Brasília, v.53, n.9, p.1053-1060, Sept. 2018 DOI: 10.1590/S0100-204X2018000900009 
slaughter, which can also contribute to the reduction of greenhouse gas emissions per animal unit (AU) (Maia et al., 2009).

Improving pasture quality increases carbon sequestration $\left(\sim 0.6 \mathrm{Mg} \mathrm{ha}^{-1} \mathrm{C}\right.$ per year in well-managed pastures vs. $\sim 0.3 \mathrm{Mg} \mathrm{ha}^{-1}$ per year in degraded pastures) and water cycle from soil surface to the atmosphere $\left(\sim 45 \mathrm{~mm} \mathrm{~m}^{-1}\right.$ vs. $\left.\sim 30 \mathrm{~mm} \mathrm{~m}^{-1}\right)$ (Maia et al., 2009; Mazzetto et al., 2015; Andrade et al., 2016). Therefore, the identification of potential areas for livestock intensification is relevant for public policies such "Plano ABC", a low-carbon agriculture plan, created in 2010 by the Brazilian government, based on financial credit for the restoration of pastures with low carrying capacity in the country.

There are several methods to estimate actual carrying capacity, both for field and remote sensing data. Yu et al. (2010) estimated pasture carrying capacity in the Golog region, in China, based on integrated data on aboveground green biomass, as well as on cattle daily food consumption and stocking rate. In Brazil, Strassburg et al. (2014) obtained a stocking rate of 0.85 $\mathrm{AU} \mathrm{ha}^{-1}$ and carrying capacity of 2.37-2.53 $\mathrm{AU} \mathrm{ha}^{-1}$, when evaluating different dry matter productions.

The objective of this work was to analyze the potential of livestock intensification in Brazil.

\section{Materials and Methods}

Data on livestock production in Brazilian municipalities, obtained from Instituto Brasileiro de Geografia e Estatística (Produção..., 2015), were used to estimate the total number of cattle in Brazil, in 2015. In the evaluated farms, herds with more than 50 animals were classified into three groups of age, according to the 2006 agricultural census data (IBGE, 2006): less than 1 year, calves and heifers; 1-2 years, steers and heifers; and above 2 years, cows, bulls, oxen/beef calves, and oxen/working calves.

Another important source of data was the Brazilian pasture synthesis map, in shapefile format, available at $\quad \mathrm{http} / / /$ maps.lapig.iesa.ufg.br/?layers $=$ pa_br_ areas_pastagens_250_2016_lapig, which is the result of a compilation work conducted by the authors of the present study at the image processing and geoprocessing laboratory of Universidade Federal de Goiás (Araújo et al., 2017). It comprises both the visual interpretation of 2015 Landsat 8 images for the Atlantic forest and Caatinga biomes, as well as of recent free-access maps for the remaining biomes, i.e., TerraClass Amazon for the Amazon (Almeida et al., 2016), TerraClass Cerrado for the Cerrado (Brasil, 2015), land use map of the Upper Paraguay River basin for the Pantanal (Monitoramento..., 2012), and IBGE maps for the Pampa (IBGE, 2010).

Dry matter yield of the pastures was obtained from moderate resolution imaging spectroradiometer (Modis) images of gross primary productivity (GPP), by selecting the MOD17A2H product (Running et al., 2004; Running \& Zhao, 2015). This product estimates dry matter yield through a biophysical model that incorporates the light use efficiency concept, estimating the incident energy fraction converted into plant tissue or used in the breathing process. This varies according to plant genetic material and to soil and climatic conditions (Hilker et al., 2008). The MOD17A2H GPP is available every eight days, with a $500-\mathrm{m}$ spatial resolution and information on incident solar radiation, water vapor deficit, and air temperature.

The total number of cattle in 2015 was multiplied by the percentage of each age group in 2006 (Figure 1). For each group, total weight - based on the average values for the Nelore breed, which makes up $85-90 \%$ of the Brazilian cattle ranching (Mousquer et al., 2014) - was converted to $\mathrm{AU}$ of $450 \mathrm{~kg}$, which was subsequently divided by the pasture area of each Brazilian municipality, in order to obtain the respective stocking rates.

Carrying capacity was determined using data on dry matter yield and the corresponding demand of the different cattle age groups, as detailed subsequently. Dry matter yield was estimated from the accumulated data of eight-day GPP, during the 2014/2015 pasture growing season, from October to March, based on a rainy season mask prepared from monthly precipitation images, obtained from the Tropical Rainfall Measuring Mission (TRMM) sensor (Arantes et al., 2017). It should be noted that GPP was only evaluated during the growing period. The reason for this is that its limiting factor in the MOD17A2H product, i.e., water vapor pressure deficit data - obtained from the Global Modeling and Assimilation Office of National Aeronautics and Space Administration -, showed values that were consistently lower than the flux tower estimates, leading to erroneous estimates of GPP with increased water deficit (Hwang et al., 2008). 

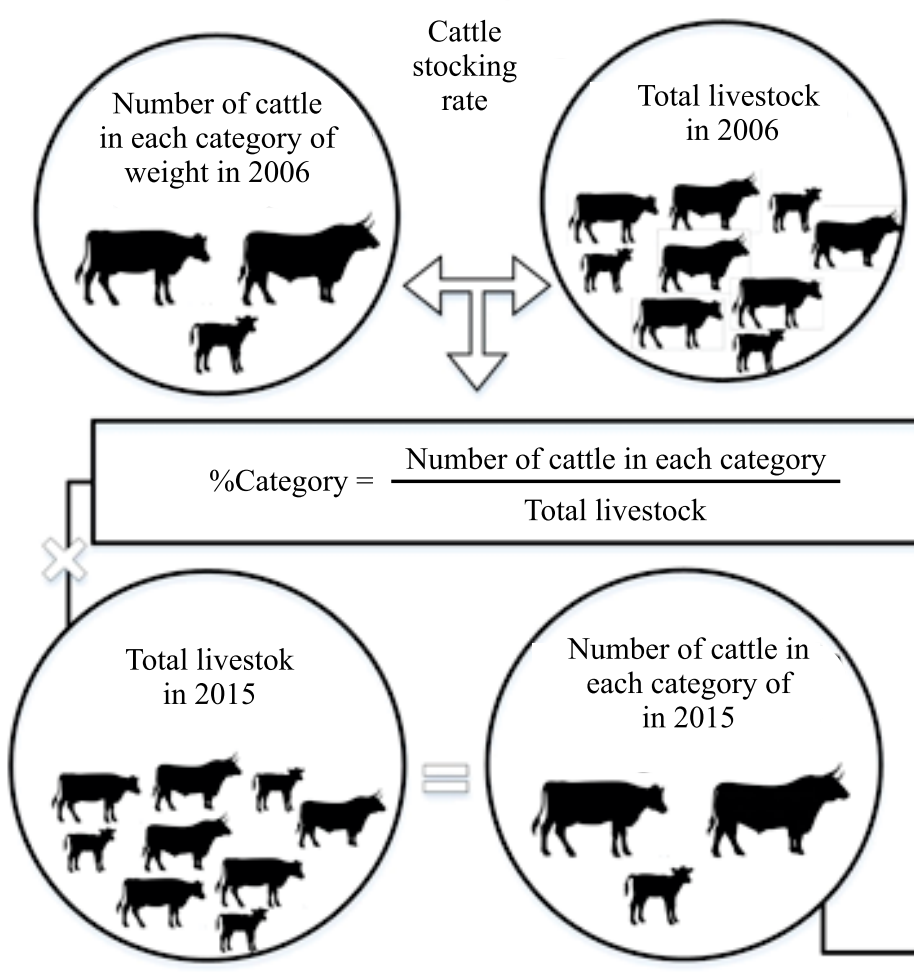

$\frac{\text { umber of cattle in each category }}{\text { Total livestock }}$

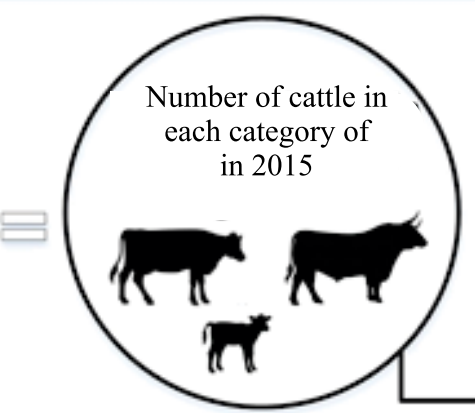

Carrying

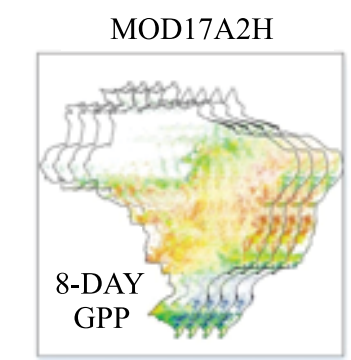

\section{Capacity}

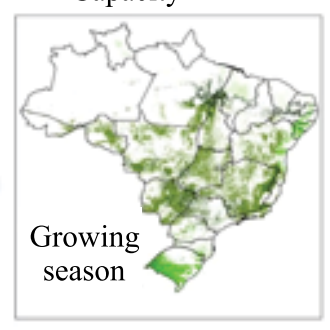

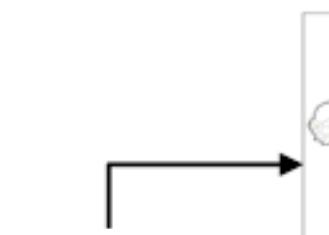

Total AU for each municipality
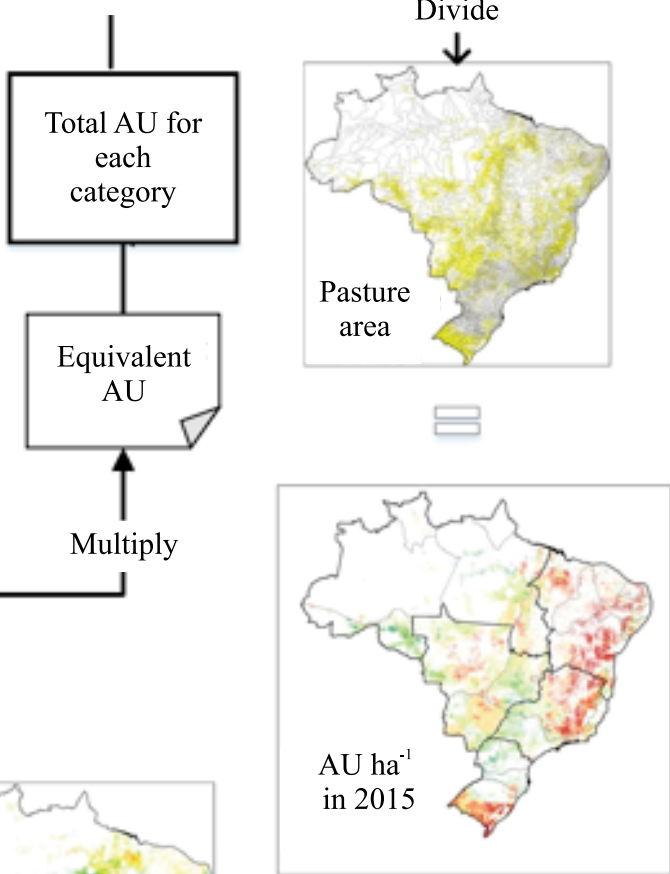

Divide -

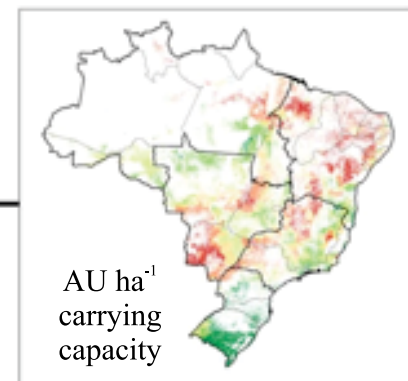

Figure 1. Flowchart for the estimation of cattle stocking rates and pasture carrying capacities in Brazilian municipalities. $\mathrm{AU}$, animal unit; DM, dry matter; and GPP, gross primary productivity. 
The GPP of the growing season was multiplied by the carbon conversion factor into biomass, i.e., the carbon ratio found in the dry matter of pastures. A factor of 2.7 was adopted since it is the typical value for Urochloa brizantha (A.Rich.) R.D.Webster [Syn. Brachiaria brizantha (A.Rich.) Stapf.], a species commonly used in Brazilian pastures (Neumann-Cosel et al., 2011). As the GPP was only considered during the growing period, a yearly-based forage production was estimated by dividing dry matter yield in the growing period by 0.8 . Then, dry matter yield during the year was divided by 365 to obtain daily yield.

To estimate daily dry matter intake, it was assumed that an AU needs, on average, 2.5\% of its live weight, i.e., $11.25 \mathrm{~kg}$ dry matter, and that forage demand is twice the amount consumed, since part of the available forage is trampled on or in senescence. Therefore, it is necessary to divide the dry matter intake by harvest efficiency (50\%), obtaining a daily demand of $22.5 \mathrm{~kg}$ of dry matter for AU. Finally, the GPP-based daily dry matter yield was divided by forage demand in order to determine carrying capacity. The intensification potential was obtained by the difference between carrying capacity and bovine stocking rate in 2015 .

\section{Results and Discussion}

The estimated Brazilian cattle stocking rate, in 2015, was $0.97 \mathrm{AU} \mathrm{ha}^{-1}$, i.e., 170 million $\mathrm{AU}$ in 175 million hectares of pasture, slightly higher than those of $0.91 \mathrm{AU} \mathrm{ha}^{-1}$ reported by Latawiec et al. (2014) and of $0.85 \mathrm{AU} \mathrm{ha}^{-1}$ by Strassburg et al. (2014). The lowest rate of $0.63 \mathrm{AU} \mathrm{ha}^{-1}$ was observed in the Northeastern region, where, according to Nasuti et al. (2013), cattle are mostly ranched in low-carrying capacity, native pastures (Figure 2). There, the states of Bahia and Pernambuco had the lowest stocking rates of 0.51 and $0.55 \mathrm{AU} \mathrm{ha}^{-1}$, respectively. It should be noted that native or highly degraded pastures present stocking rates lower than $0.5 \mathrm{AU} \mathrm{ha}^{-1}$, while well-fertilized pastures can reach up to $2.5 \mathrm{AU}^{-1} \mathrm{~h}^{-1}$ (Costa et al., 2008).

The second lowest stocking rate of $0.86 \mathrm{AU}^{\text {ha-1 }}{ }^{-1}$ was verified in the Southeastern region. The eastern portion of the states of Minas Gerais and Rio de Janeiro, which are located in hilly terrains, had even lower stocking rates of 0.70 and $0.84 \mathrm{AU} \mathrm{ha}^{-1}$, respectively. However, several states presented high values of the variable, particularly São Paulo (1.34 $\left.\mathrm{AU} \mathrm{ha}^{-1}\right)$, which concentrates more than $75 \%$ of Brazilian feedlots and a large number of slaughterhouses (Sainz \& Farjalla, 2009).

The Southern and Northern regions showed the highest stocking rates of 1.18 and $1.22 \mathrm{AU} \mathrm{ha}^{-1}$, respectively. In the Southern region, higher rates were related to soils with moderate agricultural aptitude and to high rainfall levels (Barretto et al., 2010; Alvares et al., 2014). Specifically, in the state of Rio Grande do Sul, the stocking rate of $0.81 \mathrm{AU} \mathrm{ha}^{-1}$ was below the expected and much lower than the average of 1.18 $\mathrm{AU} \mathrm{ha}^{-1}$ of the region. A plausible explanation is the possible overestimation in the area of pasturelands reported by IBGE (Araújo et al., 2017). The high stocking rates in the North are attributed to high

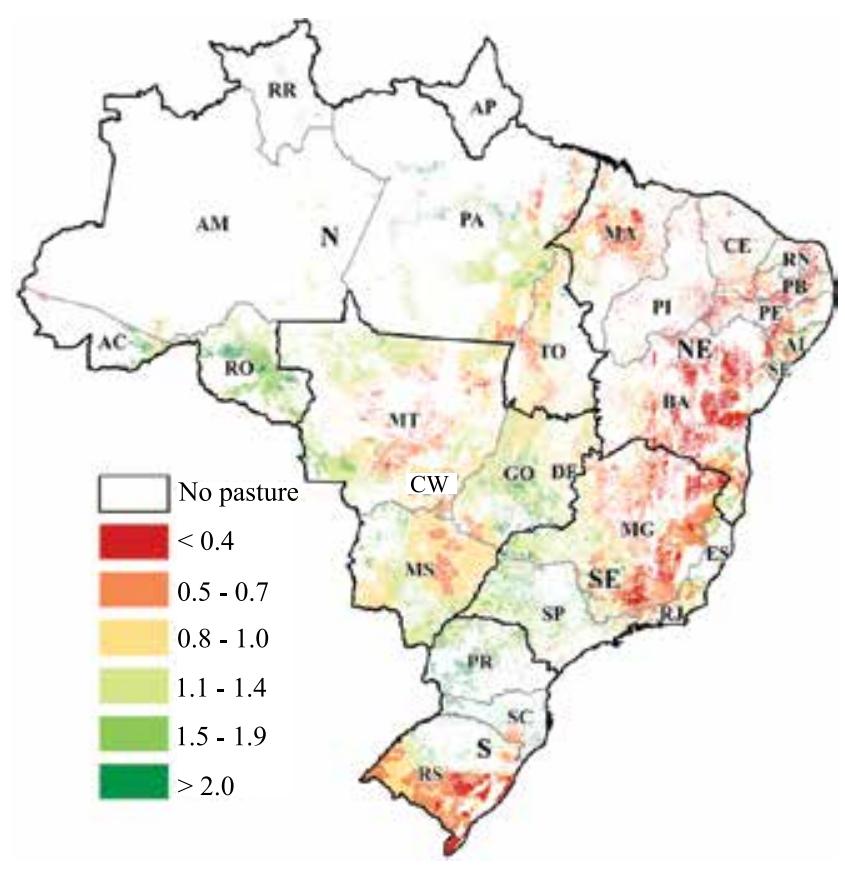

Figure 2. Cattle stocking rate (animal unit per hectare) in the Brazilian cultivated pastures in 2015. Regions: CW, Center-West; N, North; NE, Northeast; SE, Southeast; and S, South. States and federal district: RO, Rondônia; AC, Acre; AM, Amazonas; RR, Roraima; PA, Pará; AP, Amapá; MA, Maranhão; PI, Piauí; CE, Ceará; RN, Rio Grande do Norte; PB, Paraíba; PE, Pernambuco; AL, Alagoas; SE, Sergipe; BA, Bahia; MG, Minas Gerais; ES, Espírito Santo; RJ, Rio de Janeiro; SP, São Paulo; PR, Paraná; SC, Santa Catarina; RS, Rio Grande do Sul; MS, Mato Grosso do Sul; MT, Mato Grosso; GO, Goiás; TO, Tocantins; and DF, Distrito Federal. Map in shapefile format is available at: http://maps.lapig.iesa.ufg.br/?layers=pa_br_bovinos_ real_250_2017_lapig. 
rainfall levels and, more recently, to the decision of some major slaughterhouses to avoid purchasing animals from recently deforested areas of the Amazon forest, which covers great part of the region (Gibbs et al., 2015).

In the Central-West region, the stocking rate of 1.03 $\mathrm{AU} \mathrm{ha}^{-1}$ was similar to that of the South. The lowest rates were obtained in the southern and central parts of the state of Mato Grosso and in the eastern part of Mato Grosso do Sul, mainly due to the high occurrence of soils with low agricultural aptitude (Barretto et al., 2010).

In general, except for the Southeastern and Northeastern regions, stocking rates were consistently higher than those reported by Latawiec et al. (2014): 1.18 vs. $1.19 \mathrm{AU}^{-1}$ in the South; 1.22 vs. $0.97 \mathrm{AU}^{-1}$ in the North; 0.86 vs. $0.94 \mathrm{AU}^{-1} \mathrm{~h}^{-1}$ in the Southeast; 1.03 vs. $0.91 \mathrm{AU} \mathrm{ha}^{-1}$ in the Central-West; and 0.63 vs. $0.81 \mathrm{AU}^{\mathrm{Aa}} \mathrm{a}^{-1}$ in the Northeast.

Regarding the potential cattle-carrying capacity of the pastures, the estimated value was $3.60 \mathrm{AU} \mathrm{ha}^{-1}$. This means that, if the current pasture area is maintained, it is possible to increase up to 3.7 times the cattle population in Brazil (Figure 3). This value, however, is likely to be overestimated, since the GPP does not consider productivity constraints, such as limitations related to soil physical and chemical characteristics, topography, and inappropriate farm management. Despite this, a carrying capacity of $3.60 \mathrm{AU} \mathrm{ha}^{-1}$ is close to the value of 4.00 AU ha-1 reported by Simões et al. (2009) for an intensive production system with Panicum maximum Jacq. pasture, subjected to irrigation, intensive fertilizer application, and rotational grazing. According to the authors, contrasting to this value is that of $1.00 \mathrm{AU} \mathrm{ha}^{-1}$ obtained for poorly managed Urochloa decumbens (Stapf) R.D.Webster (Syn. Brachiria decumbens Stapf.) pastures, with continuous grazing and without irrigation or fertilization.

The estimated carrying capacity was higher for the South (4.81 AU ha-1) and Central-West (3.45 AU ha-1), and lower for the North (2.85 $\left.\mathrm{AU} \mathrm{ha}^{-1}\right)$. This regional gradient was similar to that verified for the current stocking rate. It should be pointed out that the carrying capacities of the Southern states Santa Catarina (5.63 $\mathrm{AU} \mathrm{ha}{ }^{-1}$ ) and Rio Grande do Sul (5.04 $\mathrm{AU} \mathrm{ha}^{-1}$ ) were considerably higher than the Brazilian average. These high values in the South partially result from errors in the TRMM-based pasture growing mask, defined for the region, which likely yielded a growth period longer than the expected.

Considering the spatial patterns of the stocking rates and the potential carrying capacities shown in the synthesis maps (Figures 2 and 3), a relatively good agreement was observed for municipalities and states located in the Center-West and North of Brazil. However, in the Southeastern region, especially in the hilly terrains, where the carrying capacity is high, the stocking rate was usually low. To a certain extent, this can be attributed to the fact that the Modis algorithm uses the deficit in water vapor pressure to represent the atmospheric water deficit, which is problematic in dry periods and in hilly terrains where runoff is relevant (Hwang et al., 2008). The maps also showed differences regarding areas subjected to periodic flooding. This

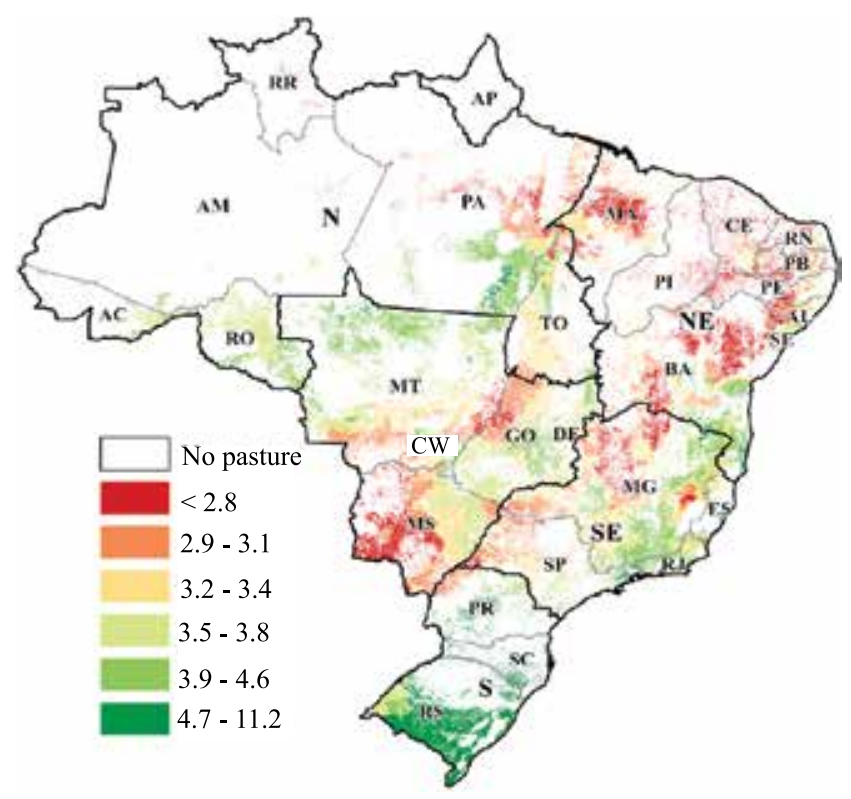

Figure 3. Potential carrying capacities (animal unit per hectare) of Brazilian pasturelands. Regions: CW, CenterWest; N, North; NE, Northeast; SE, Southeast; and S, South. States and federal district: RO, Rondônia; AC, Acre; AM, Amazonas; RR, Roraima; PA, Pará; AP, Amapá; MA, Maranhão; PI, Piauí; CE, Ceará; RN, Rio Grande do Norte; PB, Paraíba; PE, Pernambuco; AL, Alagoas; SE, Sergipe; BA, Bahia; MG, Minas Gerais; ES, Espírito Santo; RJ, Rio de Janeiro; SP, São Paulo; PR, Paraná; SC, Santa Catarina; RS, Rio Grande do Sul; MS, Mato Grosso do Sul; MT, Mato Grosso; GO, Goiás; TO, Tocantins; and DF, Distrito Federal. Map in shapefile format is available at: http://maps.lapig.iesa.ufg.br/?layers=pa_br_ capacidade_suporte_pastagem_250_2017_lapig.

Pesq. agropec. bras., Brasília, v.53, n.9, p.1053-1060, Sept. 2018 DOI: 10.1590/S0100-204X2018000900009 
was the case of the western portion of Mato Grosso do Sul, the southern part of Mato Grosso (Pantanal biome), and the northwest of Goiás (Araguaia floodplain). Flooding reduces the vegetation index values used to estimate the fraction of photosynthetically active radiation (fPAR), underestimating the corresponding GPP values (Penatti et al., 2015).

The potential of livestock intensification in Brazil was, on average, 2.63 $\mathrm{AU} \mathrm{ha}^{-1}$ (Figure 4). The highest potentials of intensification obtained were: 3.62 $\mathrm{AU} \mathrm{ha}^{-1}$ for the South and 2.59 $\mathrm{AU} \mathrm{ha}^{-1}$ for the Southeast, as these regions presented the highest differences between stocking rates and carrying capacities. However, with heavy fertilization and optimum rainfall and temperature conditions, stocking

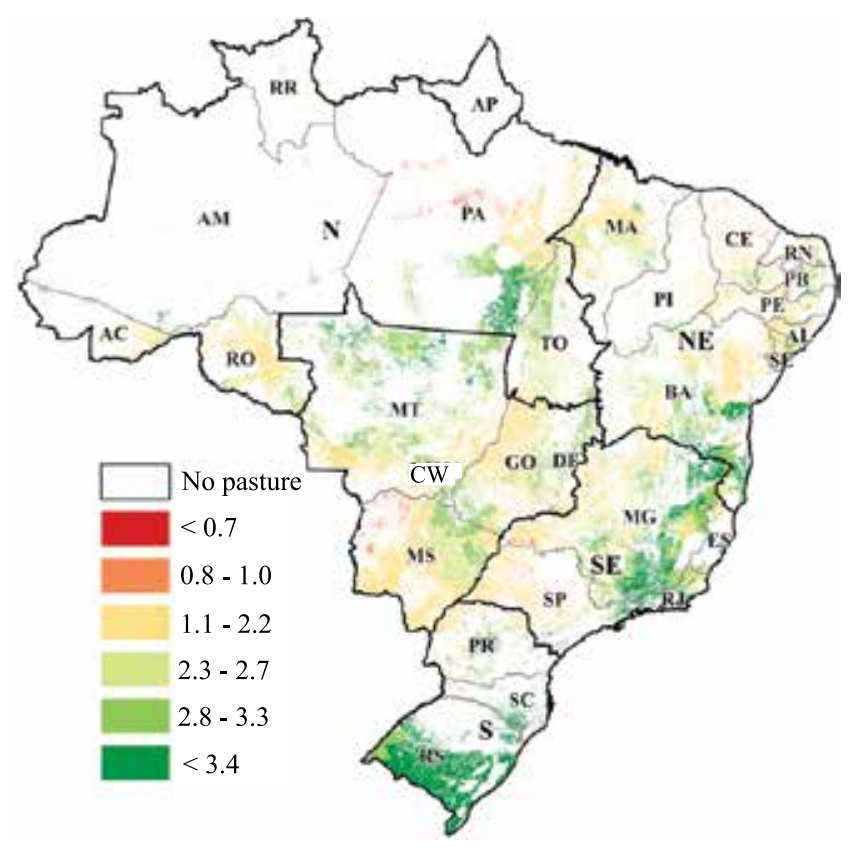

Figure 4. Potential of livestock intensification (animal unit per hectare) of Brazilian pasturelands. Regions: $\mathrm{CW}$, Center-West; N, North; NE, Northeast; SE, Southeast; and $\mathrm{S}$, South. States and federal district: RO, Rondônia; $\mathrm{AC}$, Acre; AM, Amazonas; RR, Roraima; PA, Pará; AP, Amapá; MA, Maranhão; PI, Piauí; CE, Ceará; RN, Rio Grande do Norte; PB, Paraíba; PE, Pernambuco; AL, Alagoas; SE, Sergipe; BA, Bahia; MG, Minas Gerais; ES, Espírito Santo; RJ, Rio de Janeiro; SP, São Paulo; PR, Paraná; SC, Santa Catarina; RS, Rio Grande do Sul; MS, Mato Grosso do Sul; MT, Mato Grosso; GO, Goiás; TO, Tocantins; and DF, Distrito Federal. Map in shapefile format is available at: http://maps.lapig.iesa.ufg.br/?layers=pa_br_potencial_ intensificacao_250_2017_lapig. rates may reach up to $10 \mathrm{AU} \mathrm{ha}^{-1}$ (Costa et al., 2008). Once more, it is important to emphasize that the intensification potential in the present study was based solely on climatic conditions and on the current values of stocking rate, not taking into account other environmental, social, technological, and management limitations.

A high intensification potential was verified in the eastern portion of Minas Gerais, in the southern part of Bahia, and in Pará. Sites with low potential for intensification were found in the west of São Paulo and Mato Grosso do Sul, in north of Pará, and in the northwest of Goiás. The highest potentials of intensification were observed for the states of Rio Grande do Sul (4.22 AU ha-1), Rio de Janeiro (3.32 $\mathrm{AU} \mathrm{ha}^{-1}$ ), and Minas Gerais (2.92 $\left.\mathrm{AU} \mathrm{ha}^{-1}\right)$, and the lowest for Roraima (0.83 AU ha-1), Amapá (1.34 AU ha-1), and Ceará (1.73 $\left.\mathrm{AU} \mathrm{ha}^{-1}\right)$.

Despite the obtained results, the data and models used to produce the maps of cattle stocking rates and pasture carrying capacities show several limitations. One of them is related to the accuracy of the used data. The number of cattle, for example, may vary in agricultural census data, since this information is provided by farmers. In addition, due to the lack of data on cattle composition of herds in 2015, it was necessary to use data from the 2006 agricultural census. In this case, it was assumed that changes in the composition of herds from 2006 to 2015 were negligible, which may not be true in some sites, i.e., municipalities. The cattle weight in each age category was based only on the Nelore breed, in spite of other breeds, including Gyr, Holstein, and Angus, being common in Brazil. In relation to the MOD17A2H product, the lack of specific information on soil physical and chemical characteristics, farm management, and topography certainly is a major source of error and uncertainty affecting the GPP estimates. Moreover, there are also flaws in the MOD17A2H input data, such as the low spatial resolution of the meteorological data $(1 \times 1.25)$ and the unmatched spatial resolution of fPAR (0.009) (Propastin et al., 2012). Therefore, it may be necessary to adjust the GPP to the Brazilian conditions. In the model for dry matter production, a constant carbon conversion factor for $U$. brizantha was used for the entire Brazilian territory, without considering other species, such as Andropogon spp. or Panicum spp. Additional limiting factors in the GPP-derived carrying 
capacity approach include: basing the percentage of dry matter yield adopted for the growing seasons on a single value obtained from experiments conducted just in the Center-West of Brazil; and assuming 2.5\% live weight for dry matter consumption, without considering intake variations caused by changes in the nutritional conditions of the pasture.

It should be highlighted that the models for pasture carrying capacity and intensification potential discussed here were based on estimates involving only the relationship between average daily consumption and dry matter yield controlled by climatic conditions. For a more precise estimation of this potential, other factors should also be considered, such as local limitations of soil and topography, market conditions, and impacts on greenhouse gas emissions.

\section{Conclusion}

It is possible to estimate cattle stocking rate, pasture carrying capacity based on forage production, and potential of livestock intensification by integrating data on agricultural census and remote sensing.

\section{Acknowledgments}

To Gordon and Betty Moore Foundation (grant number 4471), to Fundação de Amparo à Pesquisa do Estado de Goiás (Fapeg, grant number 201200766130154), and to Conselho Nacional de Desenvolvimento Científico e Tecnológico (CNPq, grant number 303354/2014-3), for financial support.

\section{References}

ALMEIDA, C.A. de; COUTINHO, A.C.; ESQUERDO, J.C.D.M.; ADAMI, M.; VENTURIERI, A.; DINIZ, C.G.; DESSAY, N.; DURIEUX, L.; GOMES, A.R. High spatial resolution land use and land cover mapping of the Brazilian Legal Amazon in 2008 using Landsat-5/TM and MODIS data. Acta Amazonica, v.46, p.291-302, 2016. DOI: 10.1590/1809-4392201505504.

ALVARES, C.A.; STAPE, J.L.; SENTELHAS, P.C.; GONÇALVES, J.L. de M.; SPAROVEK, G. Köppen's climate classification map for Brazil. Meteorologische Zeitschrift, v.22, p.711-728, 2014. DOI: 10.1127/0941-2948/2013/0507.

ANDRADE, R.G.; TEIXEIRA, A.H. de C.; LEIVAS, J.F.; NOGUEIRA, S.F. Analysis of evapotranspiration and biomass in pastures with degradation indicatives in the Upper Tocantins River Basin, in Brazilian Savanna. Revista Ceres, v.63, p.754760, 2016. DOI: 10.1590/0034-737x201663060002.
ARANTES, A.E.; OLIVEIRA-SANTOS, C.; FERREIRA, L.G.; FARIA, S.M. de. Determinação do início e final da estação chuvosa para o Brasil com dados TRMM e o seu uso como proxy do período de crescimento das pastagens. In: SIMPÓSIO BRASILEIRO DE SENSORIAMENTO REMOTO, 18., 2017, Santos. Anais. São José dos Campos: INPE, 2017. p.669-676.

ARAÚJO, F.M.; FARIA, A.S.; FERREIRA, L.G.; NOGUEIRA, S.H.M. Distribuição e avaliação da acuidade espacial dos mapeamentos da área de pastagem para o Brasil. In: SIMPÓSIO BRASILEIRO DE SENSORIAMENTO REMOTO, 18., 2017, Santos. Anais. São José dos Campos: INPE, 2017. p.7232-7239.

BARRetTO, A.; SPAROVEK, G.; MAULE, R. Modelagem da aptidão do meio físico para culturas agrícolas. Piracicaba: USP/ESALQ, 2010.

BOWMAN, M.S.; SOARES-FILHO, B.S.; MERRY, F.D.; NEPSTAD, D.C.; RODRIGUES, H.; ALMEIDA, O.T. Persistence of cattle ranching in the Brazilian Amazon: a spatial analysis of the rationale for beef production. Land Use Policy, v.29, p.558568, 2012. DOI: 10.1016/j.landusepol.2011.09.009.

BRASIL. Ministério do Meio. Mapeamento do uso e cobertura do Cerrado: Projeto TerraClass Cerrado 2013. Brasília, 2015. 66p.

COSTA, C.; MEIRELLES, P.R. de L.; SILVA, J.J. da; FACTORI, M.A. Evolução das pastagens cultivadas e do efetivo bovino no Brasil. Veterinária e Zootecnia, v.15, p.8-17, 2008.

EBRAHIMI, A.; MILOTIĆ, T.; HOFFMANN, M. A herbivore specific grazing capacity model accounting for spatio-temporal environmental variation: a tool for a more sustainable nature conservation and rangeland management. Ecological Modelling, v.221, p.900-910, 2010. DOI: 10.1016/j.ecolmodel.2009.12.009.

GIBBS, H.K.; RAUSCH, L.; MUNGER, J.; SCHELLY, I.; MORTON, D.C.; NOOJIPADY, P.; SOARES-FILHO, B.; BARRETO, P.; MICOL, L.; WALKER, N.F. Brazil's soy moratorium: Supply-chain governance is needed to avoid deforestation. Science, v.347, p.377-378, 2015. DOI: 10.1126/ science.aaa0181.

HERRERO, M.; HAVLÍK, P.; VALIN, H.; NOTENBAERT, A.; RUFINO, M.C.; THORNTON, P.K.; BLÜMMEL, M.; WEISS, F.; GRACE, D.; OBERSTEINER, M. Biomass use, production, feed efficiencies, and greenhouse gas emissions from global livestock systems. Proceedings of the National Academy of Sciences of the United States of America, v.110, n.52, p.20888-20893, 2013. DOI: $10.1073 /$ pnas.1308149110.

HILKER, T.; COOPS, N.C.; WULDER, M.A.; BLACK, T.A.; GUY, R.D. The use of remote sensing in light use efficiency based models of gross primary production: a review of current status and future requirements. Science of the Total Environment, v.404, p.411-423, 2008. DOI: 10.1016/j.scitotenv.2007.11.007.

HWANG, T.; KANG, S.; KIM, J.; KIM, Y.; LEE, D.; BAND, L. Evaluating drought effect on MODIS Gross Primary Production (GPP) with an eco-hydrological model in the mountainous forest, East Asia. Global Change Biology, v.14, p.1037-1056, 2008. DOI: 10.1111/j.1365-2486.2008.01556.x.

IBGE. Instituto Brasileiro de Geografia e Estatística. Censo Agropecuário 2006: resultados preliminares. 2006. Available at: <http://biblioteca.ibge.gov.br/visualizacao/periodicos/49/ 
agro_2006_resultados_preliminares.pdf $>$. Accessed on: Oct. 29 2016.

IBGE. Instituto Brasileiro de Geografia e Estatística. Projeto levantamento e classificação do uso da terra: uso da terra no estado do Rio Grande do Sul: relatório técnico. Rio de Janeiro, 2010. 152p. Available at: <http://biblioteca.ibge.gov.br/ visualizacao/livros/liv95891.pdf>. Acessed on: Feb 202017.

LATAWIEC, A.E.; STRASSBURG, B.B.N.; VALENTIM, J.F.; RAMOS, F.; ALVES-PINTO, H.N. Intensification of cattle ranching production systems: socioeconomic and environmental synergies and risks in Brazil. Animal, v.8, p.1255-1263, 2014. DOI: $10.1017 /$ S1751731114001566.

MAIA, S.M.F.; OGLE, S.M.; CERRI, C.E.P. Effect of grassland management on soil carbon sequestration in Rondônia and Mato Grosso states, Brazil. Geoderma, v.149, p.84-91, 2009. DOI: 10.1016/j.geoderma.2008.11.023.

MAZZETTO, A.M.; FEIGL, B.J.; SCHILS, R.L.M.; CERRI, C.E.P.; CERRI, C.C. Improved pasture and herd management to reduce greenhouse gas emissions from a Brazilian beef production system. Livestock Science, v.175, p.101-112, 2015. DOI: 10.1016/j. livsci.2015.02.014.

MONITORAMENTO das alterações da cobertura vegetal e uso do solo na Bacia do Alto Paraguai: porção brasileira: período de análise: 2010 a 2012. Brasília: WWF, 2012.

MOUSQUER, C.J.; HOFFMANN, A.; SIMIONI, T.A.; FERNANDES, G.A.; CASTRO, W.J.R. de; SILVA FILHO, A.S.; DALMASO, A.C.; MORAES, E.H.B.K. de. Intensificação do sistema produtivo de bovinos de corte: suplementação a pasto. Nutritime, v.11, p.3288-3308, 2014.

NASUTI, S.; EIRÓ, F.; LINDOSO, D. Os desafios da agricultura no Semiárido brasileiro. Sustentabilidade em Debate, v.4, p.276298, 2013.

NEUMANN-COSEL, L.; ZIMMERMANN, B.; HALL, J.S.; van BREUGEL, M.; ELSENBEER, H. Soil carbon dynamics under young tropical secondary forests on former pastures - a case study from Panama. Forest Ecology and Management, v.261, p.1625-1633, 2011. DOI: 10.1016/j.foreco.2010.07.023.

PAULINO, H.B.; SOUZA, E.D. de; CARNEIRO, M.A.C.; SMILJANIK JUNIOR, E. Production and quality of Brachiaria forage plants in southwestern Goiás state. Acta Scientiarum. Animal Sciences, v.33, p.341-346, 2011. DOI: 10.4025/ actascianimsci.v33i4.8960.

PENATTI, N.C.; ALMEIDA, T.I.R. de; FERREIRA, L.G.; ARANTES, A.E.; COE, M.T. Satellite-based hydrological dynamics of the world's largest continuous wetland. Remote Sensing of Environment, v.170, p.1-13, 2015. DOI: 10.1016/j. rse.2015.08.031.

POSTEL, S.L. Water for food production: will there be enough in 2025 ? Boosting the water productivity of world agriculture will be crucial to meeting future food needs. BioScience, v.48, p.629637, 1998 .

PRODUÇÃO DA PECUÁRIA MUNICIPAL. Rio de Janeiro: IBGE, v.43, 2015. 49p.

PROPASTIN, P.A.; KAPPAS, M.W.; HERRMANN, S.M.; TUCKER, C.J. Modified light use efficiency model for assessment of carbon sequestration in grasslands of Kazakhstan: combining ground biomass data and remote-sensing. International Journal of Remote Sensing, v.33, p.1465-1487, 2012. DOI: 10.1080/01431161.2011.577105.

RUNNING, S.W.; NEMANI, R.R.; HEINSCH, F.A.; ZHAO, M.; REEVES, M.; HASHIMOTO, H. A continuous satellite-derived measure of global terrestrial primary production. BioScience, v.54, p.547-560, 2004. DOI: 10.1641/0006-3568(2004)054[0547:ACSMOG]2.0.CO;2.

RUNNING, S.W.; ZHAO, M. User's guide daily GPP and annual NPP (MOD17A2/A3) products NASA Earth Observing System MODIS Land Algorithm. Version 3.0. 2015. Available at: $<$ https://www.ntsg.umt.edu/files/modis/MOD17UsersGuide2015 v3.pdf>. Accessed on: Aug. 162018.

SAINZ, R.D.; FARJALLA, Y.B. Otimização do confinamento para garantir a qualidade das carcaças e maximizar os lucros. In: SIMPÓSIO INTERNACIONAL DE NUTRIÇÃO DE RUMINANTES, 2., 2009. Botucatu. Anais. Botucatu: Unesp, 2009. v.2, p.140-155.

SIMÕES, A.R.P.; SILVA, R.M. da; OLIVEIRA, M.V.M. de; CRISTALDO, R.O.; BRITO, M.C.B. Avaliação econômica de três diferentes sistemas de produção de leite na região do Alto Pantanal Sul-mato-grossense. Agrarian, v.2, p.153-167, 2009.

STRASSBURG, B.B.N.; LATAWIEC, A.E.; BARIONI, L.G.; NOBRE, C.A.; SILVA, V.P. da; VALENTIM, J.F.; VIANNA, M.; ASSAD, E.D. When enough should be enough: improving the use of current agricultural lands could meet production demands and spare natural habitats in Brazil. Global Environmental Change, v.28, p.84-97, 2014. DOI: 10.1016/j.gloenvcha.2014.06.001.

YU, L.; ZHOU, L.; WEI, L.; ZHOU, H.-K. Using remote sensing and GIS technologies to estimate grass yield and livestock carrying capacity of Alpine grasslands in Golog Prefecture, China. Pedosphere, v.20, p.342-351, 2010. DOI: 10.1016/S10020160(10)60023-9. 